\title{
Analysis Semi-Strong Efficiency Market Testing Through of Right Issue Influence on Abnormal Return in Emitens Indonesia Stock Exchange Period 2017-2019
}

\author{
Nurul Pathonah ${ }^{1}$, Budi Purwanto ${ }^{2}$, Wita Juwita Ermawati ${ }^{2}$ \\ \{nurul24041994nurul@apps.ipb.ac.id ${ }^{1}$, budipurwanto@apps.ipb.ac.id², witaman@apps.ipb.ac.id² \\ Graduate Student at Management Science, IPB University, Bogor Indonesia ${ }^{1}$, Lecturer at Department \\ of Management, Faculty of Economics and Management, IPB University, Bogor Indonesia ${ }^{2}$
}

\begin{abstract}
.
This study aims to see the semi-strong-efficient form of the Indonesian capital market in the context of announcing rights issues. This study used 40 companies that conducted rights issues during 2017 - 2019. To prove market efficiency, study uses abnormal returns with a normality test kolmogorov-smirnov. Based on the hypothesis test there is no significant difference in expected return but there are significant differences in the actual return and CAAR. The results of the analysis concluded that the right issue announcement information has information that causes differences in investor preferences that are reflected in changes in stock prices that can result in changes in abnormal returns before and after the right issue event. Rapid reaction by the market to the information received so that it is fast in decision making and empirical results show that Indonesian capital market is expressed as semi-strong form of market efficiency.
\end{abstract}

Keywords: Actual Return, Abnormal Return, Expected Return, Right Issue, Semi Strong Form.

\section{Introduction}

The concept efficient capital market states that in an efficient market the price of securities is evaluated quickly by important information relating to securities $^{1}$. Analysis of information available in the context of decision making, the form of capital market efficiency can be reviewed in terms of informationally efficient market, and also in terms of decisionally efficient market $^{2}$. Market efficiency testing in this research is information market efficiency. This study uses event studies on the announcement of rights issues. Right issue is one of the most popular corporate action companies because

${ }^{1}$ Mallikarjunappa, T., and Dsouza, J. J. (2013). A Study of Semi-Strong Form of Market Efficiency of Indian Stock Market. Amity Global Business Review, 8.

2 Tjandra, R. (2006). Information Testing of Semi-Strong Market Efficiency on the Announcement of Dividend Initiation. Muhammadiyah University Yogyakarta 
companies do not need to bear the cost of the guarantor (underwriter) as well as an initial public offering. Companies tend to do right issues because the benefits obtained are greater than the costs to be incurred (Frijns et al. 2006). Some corporate actions carried out by emitens in Indonesia are shown in figure 1.

Corporate Actions of emitens

Indonesia Stock Exchange in 2015-2019

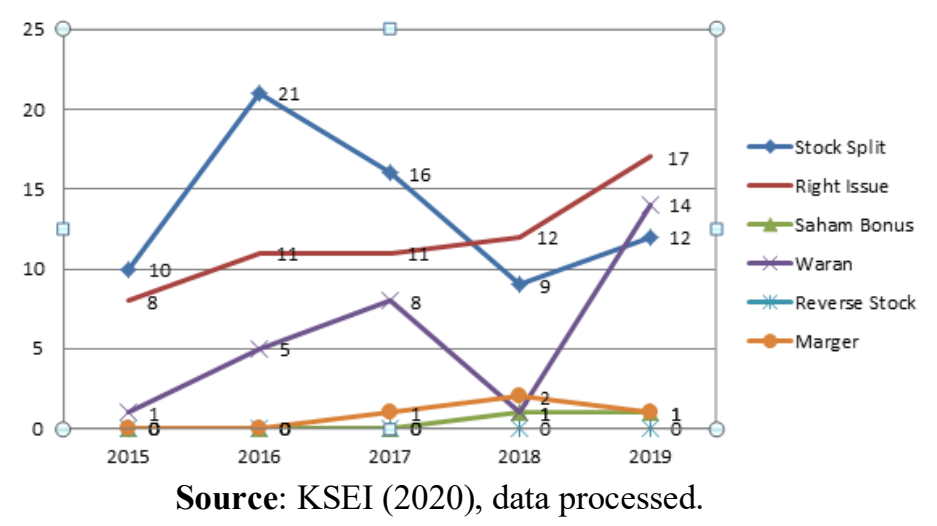

Figure 1 shows that corporate actions that tend to increase steadily from 2017-2019 carried out by the emitens of the Indonesia Stock Exchange are the right issue. Generally emitens conduct rights issues with the aim of increasing the number of shares outstanding, saving emission costs, even to cover losses (Parmitasari et al. 2016). The increase in issuers conducting rights issues is influenced by a bullish market (Putri, 2017), supported by data on the increase in the CSPI for 2017-2019. Investors need information on stock price index movements because it is one of the guidelines for investing in the capital market, especially stocks. Following the development of the CSPI is shown in Figure 2.

CSPI in 2015-2019

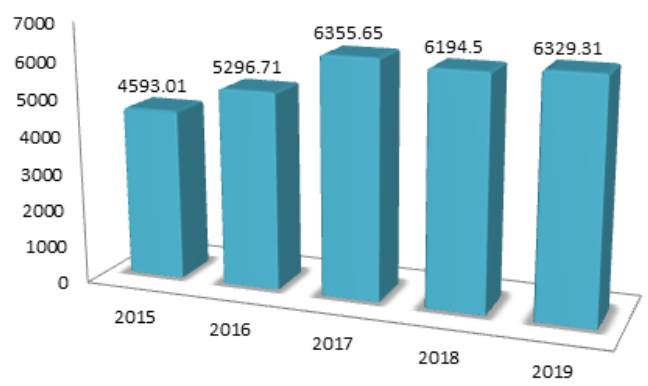

Source: Yahoo Finance (2020), data processed. 
Figure 2 shows the increase in CSPI in 2017-2019 tends to increase compared to the previous year, making emitens choose the right issue as a way to find funding with the benefit of shares more easily absorbed by the public and valuation will be expensive when the market goes up and will affect its liquidity. Liquidity is a reflection of the ability of large amounts of transactions, with low costs and short time ${ }^{3}$. An announcement containing information will provide an abnormal return to investors and vice versa (Pratama and Sudhiarta, 2014).

Dwipayana and Wiksuana's research (2017) states that the Indonesia Stock Exchange has a semi-strong efficiency in information. The semistrong efficient market hypothesis states that market efficiency is said to be semistrong when investors use historical prices and volumes as well as all published information as a basis for making stock trading decisions ${ }^{4}$. Empirical testing of the market reaction to the announcement of the rights issue is of concern to researchers. This phenomenon attracts the attention of investors in the market. Many studies have been identified in relation to bonus issues, dividend declarations, interim dividends, stock splits, mergers, etc. There is still little research on testing market efficiency at the semi-strong level in relation to the rights issue. Research by Putri et al. (2018) with the results of research on abnormal returns and trading volume activities that show no significant difference in the rights issue. Research was also conducted by Apsari and Yasa (2017), the results showed that there was a negative market reaction before and after the announcement of the rights issue. Research by Ginglinger et al. (2013); Mateus et al. (2017) found that the announcement of the rights issue is seen as bad news by investors in the capital market. Similar results were found in a study conducted by Lee et al. (2014) in their research found that investors react negatively to the announcement of rights offers in Hong Kong and the abnormal return of rights offers offers on the day of the announcement is $-12.10 \%$. Kendirli and Elmali (2016) found negative Cumulative Average Abnormal Returns (CAAR) ten days after the announcement date. It can be said that most rights issues do not have a significant effect and there are negative market reactions, although there is research conducted by (Ridho et al. 2017) showing that rights issues have a significant effect on abnormal returns and stock trading volume. Miglani (2011) observed positive abnormal returns of 32 right issues from India. They

\footnotetext{
${ }^{3}$ Blau, B. M., Griffith, T. G., and Whitby, R. J. (2018). The Maximum Bid-Ask Spread. Journal of Financial Markets, 41, 1-16.

4 Samsul, M. (2006). Capital markets and portfolio management. Jakarta: Erlangga.
} 
reported a gain of $1.42 \%$ in the shareholders wealth on the day of announcement of right issue.

The diversity of research results tends to obtain negative results, which means supporting the signaling theory model that assumes information asymmetry among various participants in the capital market. The model states that the market will react negatively because of the announcement of the addition of new shares that indicate bad news. Many causes of negative results are obtained because of bad news information received by investors that emitens do right issues to pay debts not for business expansion, volatile stock prices, poor market conditions, low company growth, higher debt capacity and poor quality in terms of market ratios, so investors are careful to exercise their rights in the rights issue. The issuance of new shares will cause the emiten shares to be diluted if Investors do not use the rights issue, because the results that are inconsistent with the hypothesis show that there is no agreement on the effect of the announcement of a rights issue with stock returns. So the authors conducted a research study with the aim to analyze how the market reaction by testing the market efficiency of a semi-strong form of corporate action right issue that affects market conditions and preferences of investors for information, and prove whether the capital market in Indonesia is classified as a semi-strong market efficiency which shows the market responds to information quickly and is relevant in accordance with the concept of an efficient market. From the above problems, the following research objectives are obtained

a) Examining whether there is an abnormal return on the Indonesian stock price from the announcement of the Right Issue.

b) Test whether there is a significant difference between the average expected return and the average actual return before and after the announcement of the rights issue.

c) Test whether the Indonesian capital market forms semi-strong market efficiency or not.

\section{Review of Literature}

\subsection{Efficient Market Hypothesis (EMH): The Concept}

Efficient Market is a market whose security prices reflect all available information ${ }^{5}$. Efficient market theory explains that investors cannot consistently obtain abnormal returns, if the investor does not always enter the

5 Tandelilin, E. (2010). Portfolio and Investment Theories and Applications. Yogyakarta: Canisius Publishers. 
information he has received or is available in making decisions when making a transaction. Having quality and relevant information, investors can assess the performance prospects of the emitens so that investors have a picture of the risks and expected returns on funds that have been or will be invested ${ }^{6}$.

${ }^{7}$ There are three levels of capital market efficiency states, that is (1) The weak efficient market hypothesis occurs when investors use historical price and volume considerations in making stock trading decisions. (2) The semistrong efficient market hypothesis occurs when investors use consideration of historical prices, historical volumes, and if prices reflect the published information. (3) The strong efficient market hypothesis occurs when investors use more complete data considerations such as historical prices and volumes, published information, as well as private information in making decisions about buying and selling shares.

\subsection{Information Asymmetry}

${ }^{8}$ Explains that information asymmetry occurs when two parties do not have the same information. Some information is confidential and not many parties know the information.

\subsection{Signaling Theory}

Signal theory is a theory that describes a condition that describes a company ${ }^{9}$. Signal theory states that any event related to the company's condition will generate a potential load of information received as a signal. Trading volume and stock prices will change when an announcement contains information that has an impact on market reactions (Wistawan and Widanaputra, 2013). Corporate communication is a signal from company managers to investors, to minimize information asymmetry ${ }^{10}$.

\subsection{Previous Study}

Several studies have tested semi-strong forms such as block trading, stock splits, option listing, margers, dividends, annual income etc. The results of

\footnotetext{
${ }^{6}$ Zaqi, M. (2006). Indonesian Capital Market Reaction Against Economic Events and Domestic SocioPolitical Events (Study on Lq45 Stocks on the JSE Period 1999-2003) (Doctoral dissertation, Diponegoro University Postgraduate program).

${ }^{7}$ Hanafi, M. M. (2014). Financial Management, Seventh Printing. First edition. BPFE. Yogyakarta.

${ }^{8}$ Connelly, B. L., Certo, S. T., Ireland, R. D., and Reutzel, C. R. (2011). Signaling theory: A review and assessment. Journal of management, 37(1), 39-67.

${ }^{9}$ Fahmi, I. (2013). Introduction to the Capital Market. Bandung: Alfabeta.

${ }^{10}$ Goetzmann, W. N., Brown, S. J., Gruber, M. J., and Elton, E. J. (2014). Modern portfolio theory and investment analysis. John Wiley and Sons, 237.
} 
critical reviews by several researchers are: Salameh and Albahsh (2011) tested a semi-strong efficient market form on the Palestinian stock exchange with the event study methodology. The research results prove the inefficiency of the stock market at a semi-strong level. Shihadeh and Hannon (2016) tested the efficiency of the Palestinian Stock Exchange in semi-strong form on cash dividends for nine years from 2006 to 2014. The results prove the inefficiency of the Palestinian Exchange in a semi-strong form.

Ikram and Nugroho (2014) tested the efficiency of the semi-strong Indonesian stock market on the merger announcement from 2000 to 2013. The event study methodology with a 30-day window, the results prove the efficiency of a semi-strong form on the Indonesia Stock Exchange. Dhar and Chhaochharia (2008) analyzed the announcement of the stock split and bonus issue on the National Stock Exchange (NSE) with an event study. Both of these events had a very positive influence. This study supports the efficient Indian Stock Market in a semi-strong form.

\subsection{Research Gap}

Several studies from around the world examine the semi-strong forms of efficient markets, from developed to developing countries. Researchers observed that most of the semi-strong form tests have been carried out on specific events such as bonus issuance announcements, stock split announcements, dividend announcements etc. Very few studies on testing of market efficiency in semi-strong level in relation to right issue were identified. Pariticulary in Indonesia such studies are very less. Only look at the market reaction of the right issue action and tends to get negative abnormal returns because investors get bad news that will affect the market reaction. Therefore, this study tries to analyze the rights issue in the Indonesian capital market in a semi-strong form. With the aim of this research to help investors determine the impact of rights issue on market prices and market efficiency.

\section{Research Methodology}

\subsection{Method of Data Collection}

The population in this study are companies listed on the Indonesia Stock Exchange (BEI) that conducted rights issues in the 2017-2019 period. The type of data used is secondary data, using company daily closing price data and daily closing price data from market index return data. The duration of the event study is specified in the forecast window, The estimated time period is set as 120 days before the event (assumed to be -125 to -6 ). And a window 
period of 11 days -5 (before the announcement of the rights issue) and +5 (after the announcement of the rights issue). The sampling method used was purposive sampling. Several criteria for determining the sample, namely:

1. The Indonesian Capital Market (IDX), TICMI, KSEI must have complete information regarding the date of the announcement of the right issue held by the company.

2. There were no other events or corporate actions that occurred in the company and confounding events during the observation period.

Based on the above criteria, there are 40 companies that conducted rights issues from January 2017 to December 2019 on the IDX.

\subsection{Research Framework}

This study uses a quantitative method, namely an event study. Event study is a research technique for assessing the impact of certain events on a company's stock price ${ }^{11}$. The event study analyzes the market reaction to an event whose information is announced to the public, which if there is an abnormal return after the announcement is announced, it can be said that the announcement contains information and vice versa. The market becomes efficient when investors react quickly to absorb information. If investors are slow to absorb information, the market is inefficient in a semi-strong form based on available information ${ }^{12}$.

\footnotetext{
${ }^{11}$ Bodie, Z., Kane, A., and Marcus, A. J. (2013). Investments and portfolio management. McGraw Hill Education (India) Private Limited.

${ }^{12}$ Hartono, J. (2003). Portfolio Theory and Investment Analysis Fifth Edition. Yogyakarta: BPFE.
} 


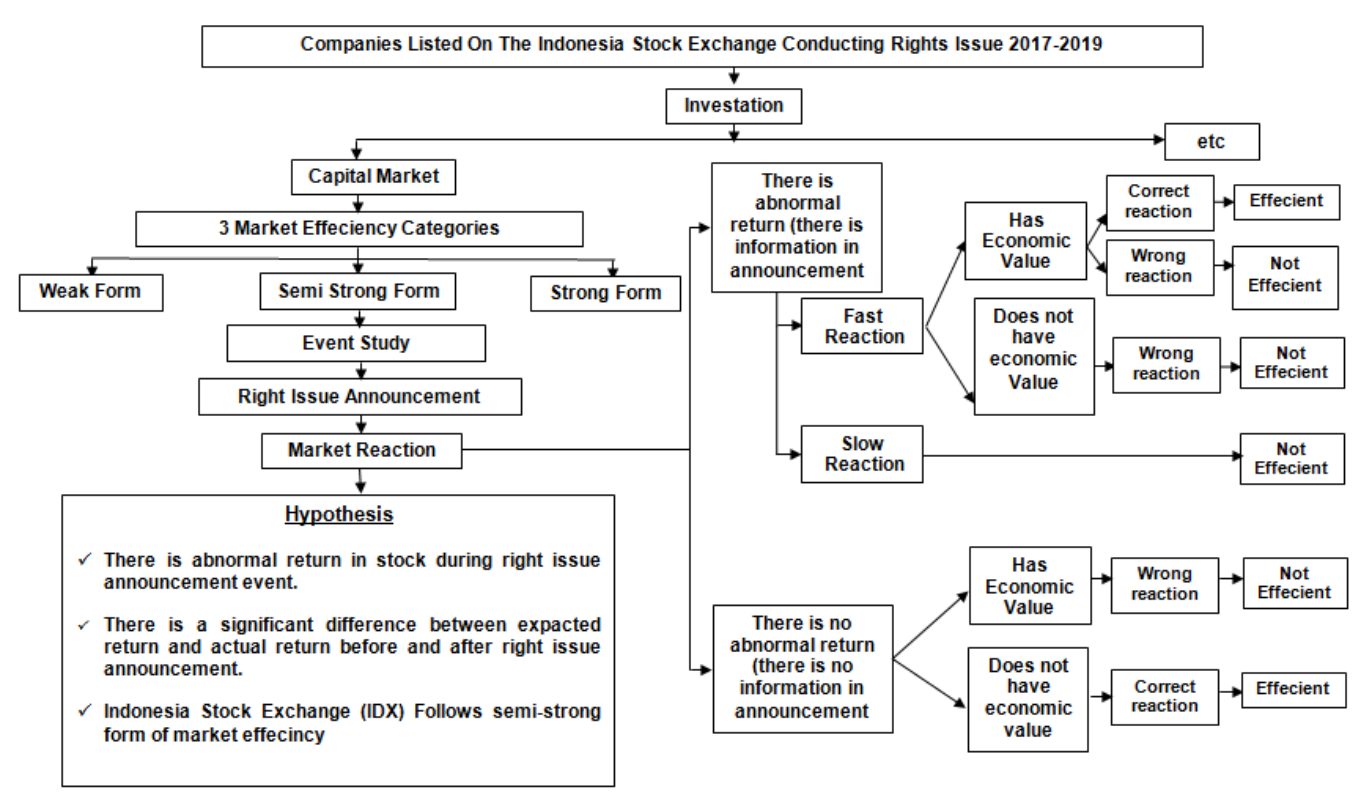

Figure 3. Research Framework

\subsection{Hypothesis Development}

Market reaction is indicated by changes in prices of the relevant shares ${ }^{13}$. Right issue is very beneficial for investors and companies, because it can increase the company's liquidity, attract new investors to invest, and increase the proportion of shares owned by new investors. Some investors try to increase the return (abnormal return) to get more profit. Research by Epriyeni (2014) and Rohit et al. (2016), concluded that there was a difference in return around the announcement of the right issue. Therefore, the researcher developed a hypothesis, namely:

H1: There is an abnormal return at the time of the announcement of the right issue, before and after the announcement of the right issue.

$\mathrm{H} 2$ : There is a significant difference between the expected return and the actual return before and after the announcement of the rights issue.

An efficient market does not have the same reaction as an inefficient market when new information is released. Gunawan's research (2016) on the Jakarta Stock Exchange is classified as semi-strong form efficiency. From this theory, the researcher develops a hypothesis, namely:

\footnotetext{
${ }^{13}$ Hartono, J. (2015). The tenth edition of portfolio theory and investment analysis. Yogyakarta: Bpfe.
} 
H3: The Indonesia Stock Exchange is stated in the form of a semi-strong market.

\subsection{Method of Analysis}

In Hartono's book (2015), the actual return formula is as follows:

$$
R_{i t}=\frac{\left(\boldsymbol{P}_{i t}-\boldsymbol{P}_{i t-1}\right)}{\boldsymbol{P}_{i t-1}}
$$

where Pit is the price of share $\mathrm{i}$ today, Pit-1 is the price of share $\mathrm{i}$ on the previous day. To calculate real market returns, a market index price is required. The formula for the market index price is as follows:

$$
\mathrm{R}_{\mathrm{mt}}=\frac{\mathrm{IHSG}_{\mathrm{t}}-\mathrm{IHSG}_{1-\mathrm{t}}}{\mathrm{IHSG} \mathrm{IH-t}_{1-\mathrm{t}}}
$$

Expected stock return i for day t, E (Rit) is calculated by placing the value of Rmt and the OLS estimate of $\alpha \mathrm{i}$ and $\beta \mathrm{i}$ respectively into the following equation $^{14}$ :

$$
\mathrm{E}(\mathrm{Rit})=\alpha \mathrm{i}+\beta \mathrm{i} \mathrm{Rmt}
$$

Abnormal return (ARit) is the difference between the actual return (Rit) and the expected return E (Rit). The formula is as follows:

$$
\text { ARit }=\text { Rit }-E(\text { Rit })
$$

Cumulative Average Abnormal Return (CAARt) is the sum of abnormal returns during the observation period of 5 days before and 5 days after the date of the announcement of the right issue then divided by the number of samples (n), the average is used to determine whether there are differences in abnormal returns before and after the announcement of the right issue. Has the formula:

$$
\operatorname{CAAR}_{t}=\frac{\sum \mathrm{AR}_{\mathrm{it}}}{\mathrm{n}}
$$

\footnotetext{
${ }^{14}$ Chakraborty, P. (2011). Semi-Strong Form of Pricing Efficiency of Indian Stock Market-An Empirical Test in The Context Of Stock-Split Announcements. International Journal of Multidisciplinary Management Studies, 1(2), 1-13.
} 


\subsection{Normality Test Method}

Normality test to test whether in a model has a normal data distribution or $\operatorname{not}^{15}$. A good model is to have a normal or close distribution. Normality test using one sample kolmogorov smirnov's when the mean are determined ${ }^{16}$. if the significant value $>0.05$, then the data is normally distributed, and significant $<0.05$, then the data is not normally distributed. If the data is normally distributed then paired sample t-test is used to test the hypothesis, but if the data is not normally distributed then the Wilcoxon signed ranks test is used.

\subsection{Paired Sample T-Test}

The purpose of paired sample t-tests is to determine whether there are significant differences in the population based on averages. In addition, this test also came from the same subject or one size from a pair of subjects ${ }^{17}$. The formula for paired sample t-test:

$$
\begin{gathered}
\mathrm{t}_{\mathrm{htuwaz}}=\frac{\overline{\mathrm{d}}}{\mathrm{dd} / \sqrt{\mathrm{n}}} \\
\overline{\mathrm{d}}=\mathrm{X} \mathrm{X}-\mathrm{Xd} \\
\overline{\mathrm{d}}=\sum \frac{\mathrm{d}}{\mathrm{n}} \\
\mathrm{Sd}=\sqrt{\frac{\sum \mathrm{d}^{2}-\frac{\left(\sum \mathrm{d}\right)^{2}}{n}}{\mathrm{n}-1}}
\end{gathered}
$$

\subsection{Wilcoxon Signed Rank Test}

The Wilcoxon sign rank test is used because the selection is made of two samples that are related to each other. The formula to calculate:

$$
\begin{gathered}
Z=\frac{T-E(T)}{\sigma_{t}} \\
E(T)=\frac{n(1+n)}{4} \\
\sigma_{t}=\sqrt{\frac{n(n+1)(2 n+1)}{24}}
\end{gathered}
$$

15 Ghozali, I. (2016). Analysis Application with IBM SPSS 23. Semarang Program: Diponegoro University Publisher Agency

${ }^{16}$ Melbourne, D. A. (2014). A New method for Testing Normality based upon a Characterization of the Normal Distribution.

${ }^{17}$ Kusrini, (2008). Analysis of the Impact of Announcement of Right Issue and Information Asymmetry on Cost of Equity. " Thesis UIN. 2008. 
where $\mathrm{T}$ is the smallest number of sequences of signs $(+)$ or $(-)$ and $\mathrm{N}$ is the number of samples in a group. Decision making criteria, if Sig $>0.05$ then Ho is accepted means there is no significant difference and if Sig $<0.05$ then Ho is rejected means there is a significant difference.

\section{Analysis and Discussion}

\subsection{Descriptive Statistics}

Descriptive statistics Aims to explain the general picture of the distribution and behavior of sample data ${ }^{18}$.

Table 1

Descriptive Statistics Actual Returns, Expected Returns, and CAAR

Before and After Announcement of Right Issue

\begin{tabular}{|c|c|c|c|c|c|}
\hline & $\mathbf{N}$ & Minimum & Maximum & Mean & $\begin{array}{c}\text { Std. } \\
\text { Deviation }\end{array}$ \\
\hline Actual_Before & 40 & -.0418 & .2495 & .02078 & .051072 \\
Actual_After & 40 & -.1062 & .0872 & -.00511 & .039840 \\
Expected_Before & 40 & -.0139 & .0076 & .00079 & .003682 \\
Expected_After & 40 & -.0034 & .0084 & .00127 & .002767 \\
CAAR_Before & 40 & -.0437 & .2538 & .02000 & .051880 \\
CAAR_After & 40 & -.1145 & .0837 & -.00637 & .040074 \\
Valid N (listwise) & 40 & & & & \\
\hline
\end{tabular}

Data processed (2020)

Table 1 explains the results of descriptive statistics with the acquisition of average actual returns, expected returns and abnormal returns that are positive before the announcement of the rights issue of $0.0207,0.0036,0.0127$ and negative after the announcement of the right issue by $-0.0051,-00637$, except the expected expected return is positive after the announcement of the rights issue of 0.0012 . The results of the data above show that the overall average is positive, so it shows that the rights issue conducted by emitens has enough information content to give investors an abnormal return around the announcement of the right issue event during the 11 days of observation. The following is a graph of the average actual returns, expected returns before and after the announcement of the right issue in figure 4.

${ }^{18}$ Ghozali, I. (2013). Multivariate Analysis Application with the IBM SPSS Program. Issue 7. Semarang: Diponegoro University Issuing Agency. 


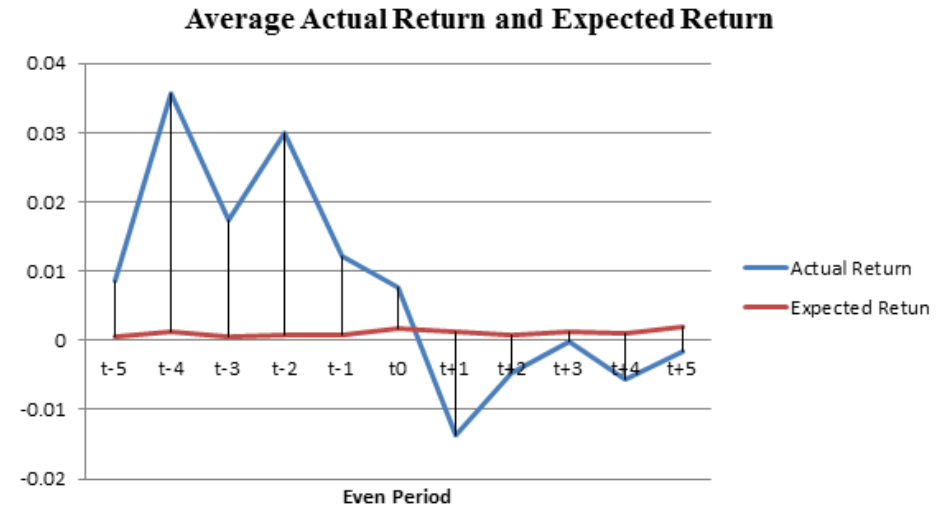

Figure 4. Data processed (2020)

Figure 4 shows the period after the announcement of the right issue resulting in an average of actual return lower than the average before the announcement of the rights issue, as well as different fluctuations with expected returns that tend to be stable. This shows that the issuance of rights issues that will be issued and distributed to the market by the emitens can be absorbed by some market participants well because they find a difference between the actual return and expected return before and after the announcement, so they can provide benefits. The actual return value is used as a measure of company performance. Actual returns are also useful in determining expected returns and future risks. This difference is a picture of risk that must be considered by investors, because the greater the deviation or difference, the greater the level of risk that will be obtained. For the abnormal return value for 11 days of the observation period the minimum value of 0.015 is obtained at $\mathrm{t}+1$ and the maximum value of 0.0343 at $\mathrm{t}-4$ can be seen in Figure 5.

Cumulative Average Abnormal Return

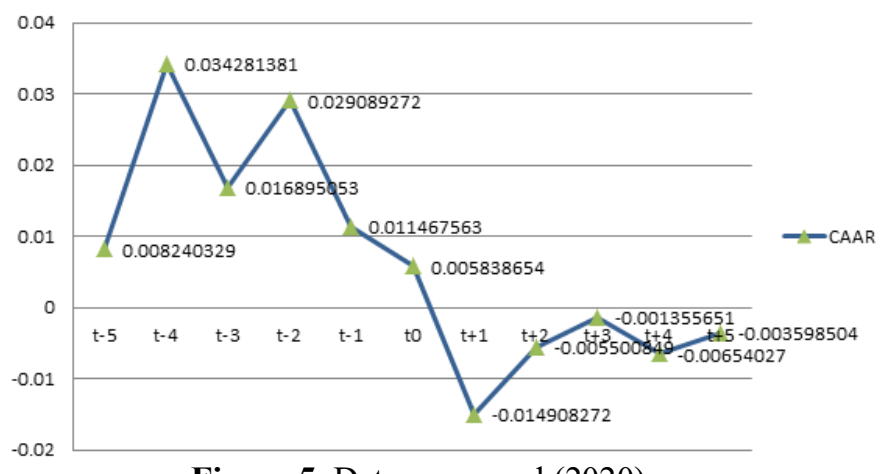

Figure 5. Data processed (2020) 
Figure 5. shows on days $\mathrm{t}-3, \mathrm{t}-1, \mathrm{t} 0, \mathrm{t}+1$ and $\mathrm{t}+4$, investors get negative abnormal returns. This implies that the market reacts more intensely to any bad news and shows investors are more inclined to sell securities that cause share prices to fall (Mandal and Rao, 2010). Inconsistency is indicated by information leakage which can be seen by the existence of a high average positive and abnormal return before the announcement of the rights issue at $\mathrm{t}-4$ and $\mathrm{t}-2$ which causes investors to react early to gain profits. Information leakage caused by insider trading. That means some investors have a relationship or relationship with the company. Then decreased dramatically at $\mathrm{t}+1$ or after the announcement of the rights issue and rose again at $\mathrm{t}+3$ and fluctuations occurred to $t+5$. This shows that the announcement of the rights issue contains enough information to make the market react where there is a fluctuation in abnormal returns before and after the announcement of the rights issue. It is possible that investors and the market will be less enthusiastic about the announcement of the rights issue held by the company, besides that they see the company's bad prospects so that they give a negative response to the company which is shown with negative abnormalities after the rights issue event. Because the empirical results show negative abnormal returns after the rights issue, the Indonesian capital market can be classified as efficient. Before testing the hypothesis, it is necessary to know whether the data is normally distributed or not.

\subsection{Data Normality Test}

Testing normality using Kolomogronov-Smirnov. If the data has a value of $>(\alpha 0.05)$, it can be concluded that the data is normally distributed.

Tabel 2. Kolomogronov-Smirnov One Sample Test

\begin{tabular}{|ll|r|r|r|r|r|r|}
\hline & & \multicolumn{1}{c}{$\begin{array}{c}\text { Actual- } \\
\text { before }\end{array}$} & $\begin{array}{c}\text { Actual- } \\
\text { after }\end{array}$ & $\begin{array}{c}\text { Expected- } \\
\text { Before }\end{array}$ & $\begin{array}{c}\text { Expected- } \\
\text { After }\end{array}$ & $\begin{array}{c}\text { CAAR- } \\
\text { Before }\end{array}$ & $\begin{array}{c}\text { CAAR- } \\
\text { After }\end{array}$ \\
\hline $\mathrm{N}$ & 40 & 40 & 40 & 40 & 40 & 40 \\
Normal & Mean & .02078 & -.00511 & .00079 & .00127 & .02000 & -.00637 \\
Parameters ${ }^{\mathrm{a}, \mathrm{b}}$ & Std. Deviation & .051072 & .039840 & .003682 & .002767 & .051880 & .040074 \\
& & .285 & .267 & .115 & .127 & .276 & .264 \\
Most Extreme & Absolute & .285 & .206 & .102 & .127 & .276 & .194 \\
Differences & Positive & -.215 & -.267 & -.115 & -.057 & -.208 & -.264 \\
& Negative & 1.801 & 1.689 & .729 & .802 & 1.748 & 1.669 \\
Kolmogorov-Smirnov Z & .003 & .007 & .662 & .541 & .004 & .008 \\
\hline
\end{tabular}

Data processed (2020)

Based on table 2, the significance value of the average actual return and CAAR before and after the announcement of the right issue are not normal 
because the significance value is $<\alpha 0.05$. While the expected return value before and $>\alpha 0.05$, so the expected data is normally distributed. Then the expected return hypothesis test uses paired sample t-test. As for the actual return and CAAR use the Wilcoxon Signed Rank Test because the data is not normally distributed.

\subsection{Hypothesis Testing}

Hypothesis testing for this study uses paired sample t-test and Wilcoxon sign rank test. If the data has a significance value $<\alpha(0.05)$, it can be concluded that there are significant differences.

Table 3. Paired Sample T-Test on Expected Return

\begin{tabular}{|c|c|c|c|}
\hline No & Period & $\begin{array}{c}\text { Asymp. Sig. (2- } \\
\text { tailed) }\end{array}$ & Information \\
\hline 1 & $\begin{array}{c}\text { Epected Return } \\
\text { Before and After }\end{array}$ & 0.275 & Not Significant \\
\hline
\end{tabular}

Data processed (2020)

Based on table 3, the results of testing $0.275>0.05$ show that there is no significant difference between the expected return before and after the rights issue. Expected return is a return that is expected to be obtained by investors in the future and has not yet occurred ${ }^{19}$. So that the results of this hypothesis test can be a reference that there is no significant difference between before and after the rights issue, from this result investors will be more careful in exercising their rights and is a return that is anticipated by investors in the future $^{20}$.

Table 4. Wilcoxon Sign Rank Test Actual Return and CAAR

\begin{tabular}{|c|c|c|}
\hline & $\begin{array}{c}\text { Actual Before - Actual } \\
\text { After }\end{array}$ & $\begin{array}{c}\text { CAAR Before - CAAR } \\
\text { After }\end{array}$ \\
\hline Z & $-2.086^{\mathrm{a}}$ & $-2.124^{\mathrm{a}}$ \\
$\begin{array}{c}\text { Asymp. Sig. (2- } \\
\text { tailed) }\end{array}$ & .037 & .034 \\
\hline
\end{tabular}

Data processed (2020)

\footnotetext{
${ }^{19}$ Hermuningsih, S., Rahmawati, A. D., and Mujino, M. (2018). Factors That Affect Stock Return. Journal of Economics and Business, 19 (3), 78-89.

${ }^{20}$ Mardhiyah, A. (2017). The Role of Return and Risk Analysis in Investments. Journal of Islamic Economics and Business, 2 (1)
} 
Based on table 4, the actual return test results before and after the right issue are $0.037<0.05$ and CAAR $0.034<0.05$. The results showed that there were significant differences with the criteria $<\alpha(0.05)$, the hypothesis was accepted. The results of the study are the same as (Gajewski and Ginglinger, 2002; Shahid et al. 2010) examining the event of the announcement of a right issue with the results of the study that abnormal returns differ significantly around the announcement of the right issue.

This study shows that the announcement of a rights issue affects prices in the market, which means market participants or investors react to the announcement of a rights issue, the announcement of a rights issue is widely available to all market participants at the same time and to obtain cheap prices from the issuance of a rights issue. This condition occurs because investors or market participants are able to understand and interpret information quickly and well. Associated with signaling theory states that there are events that can provide a signal to the reaction of information in the market. Based on the results of the analysis above, it can be concluded that the right issue announcement information has information that causes differences in investor preferences that are reflected in changes in stock prices that can cause changes in abnormal returns before and after the right issue event. Rapid reaction by the market to the information received so that it is fast in decision making and empirical results show that the Indonesian capital market is expressed as a semi-strong form of market efficiency.

\section{Conclusion}

In this study, conclusions can be drawn based on the formulation of the problem as follows: Hypothesis that tests whether there is a difference in abnormal returns before and after the announcement of a rights issue, which shows the market reaction at the time of the rights issue, meaning that at the time of the announcement of the rights issue there has been sufficient information to influence preferences investors in making investment decisions are supported. The hypothesis that investigates whether there is a significant difference between expected return and actual return before and after the announcement of the rights issue. The actual rate of return is supported by a significant difference whereas it is expected that there is no significant difference but the value tends to be stable. The hypothesis that the Indonesia Stock Exchange is expressed is a form of market efficiency that is semistrong supported. 


\section{Limitation and Suggestion}

The limitation of the study does not differentiate the research sample in announcing the right issue to provide information on good news or bad news and without considering the type of company and also the state of the company, for further research in choosing a sample can consider the type of company and also the state of the company whether in a state of loss or profit. Emitens who conduct rights issues and who will do rights issues should pay more attention to the information to be launched. Considering the motivation and objectives of investors in purchasing shares vary greatly, so it is important for emitens to maintain the stability of stock prices by taking into account market conditions including economic, political, and social conditions so that the decisions taken support the right issue policy and the momentum can be put to good use by investors so can have an impact on increasing company liquidity.

\section{Acknowledgment}

We thank the Postgraduate School of Management Science of IPB University as an institution that grants research permission for writers.

\section{Reference}

[IDX] Indonesia Stock Exchange. (2020). Listed Company Profile. [Accessed 2020 May 28]; Available at https://www.idx.co.id/company-noted/action-corporations/

[IDX] Indonesia Stock Exchange. (2020). Listed Company Profile. [Accessed 2020 June 14]; Available at https://www.idx.co.id/company-noted/prospektus/

[IDX] Indonesia Stock Exchange. (2020). Stock trading summary. [Accessed 2020 June 14]; Available at https://www.idx.co.id/data-pasar/ringkasan-perdagang/ringkasan-saham/

[JKSE] Jakarta Composite Index. (2020). Movement of the Composite Stock Price Index (CSPI). [Accessed 2020 May 28]; Available at https://finance.yahoo.com/quote/\%5EJKSE/

[KSEI] Indonesian Central Securities Depository. (2020). Corporate Action Schedule (Right Issue). [Accessed 2020 June 14]; Available at https://www.ksei.co.id/publications/corporate-action-schedules/rights-distribution.

Apsari, I. A. W. P., and Yasa, G. W. (2017). Analysis of Market Reactions to Announcements of Right Issues in Go Public Companies Listed on the IDX. E-Journal of Accounting, Udayana University, 18 (2), ISSN 1343-1368.

Epriyeni, A. (2014). Effect of Announcement of Mergers, Acquisitions and Right Issues on Abnormal Stock Returns on the Indonesia Stock Exchange.

Dhar, S., and Chhaochharia, S. (2008). Market reaction around the stock splits and bonus issues: some Indian evidence. Available at SSRN 1087200.

Dwipayana, I. G. N. A. P., and Wiksuana, I. G. B. (2017). Market Efficiency Testing on the Indonesia Stock Exchange. E-Journal of Management of Udayana University, 6 (4), 2105-2132. 
Frijns, B., Navissi, F., Tourani-Rad, A., and Tsai, L. (2006). Stock Price Performance Of Seasoned Equity Offerings: Completed Vs Withdrawn. Managerial Finance.

Ginglinger, E., Matsoukis, L., and Riva, F. (2013). Seasoned equity offerings: Stock market liquidity and the rights offer paradox. Journal of Business Finance and Accounting, 40(1-2), 215-238.

Gajewski, J. F., and Ginglinger, E. (2002). Seasoned Equity Issues In A Closely Held Market: Evidence From France. Review of Finance, 6(3), 291-319.

Gunawan, B. (2016). Capital Market Efficiency Analysis "Semistrong Form Tests" with the announcement of "Right Issue" on the Jakarta Stock Exchange. Journal of Accounting and Investment, 5 (2), 248-274.

Ikram, F., and Nugroho, A. B. (2014). Cumulative average abnormal return and semistrong form efficiency testing in indonesian equity market over restructuring issue. International Journal of Management and Sustainability, 3(9), 552-566.

Kendirli, S., and Elmali, M. E. (2016). The effects of right offering announcements on returns of shares of deposit banks traded in istanbul stock-exchange. Journal of Economic Development, Environment and People, 5(1), ISSN-L 2285-3642 74-82.

Lee, C. C., Poon, W. C., and Sinnakkannu, J. (2014). Why Are Rights Offers In Hong Kong So Different? Pacific Basin Finance Journal, 26, 176-197.

Mateus, C., Farinha, J., and Soares, N. (2017). Price Discounts In Rights Issues: Why Do Managers Insist On What Investors Hate? European Business Review, 29(4), 457 475.

Miglani, P. (2011). An empirical analysis of impact of right issues on shareholders returns of Indian listed companies. Researchers World, 2(4), 169.

Mandal, N., and Rao, N. K. (2010). "Semi-Strong Form of Indian Stock Market Efficiency: An Empirical Study". Vilakshan, XIMB Journal of Management, Vol. VII, Issue No. 1, March 2010

Putri, E. L. L. (2017, November 9). Bullish Market, Emitens Intense Right Issue. Kontan.Co.Id, p. 1. (https://www.kontan.co.id/news/pasar-bullish-emiten-gencarrights-issue. Accessed on June 14, 2020)

Parmitasari, R. D. A., and Kandi, R. (2016). Stock Return Analysis Before and After Announcement of Right Issue in Banking Companies Listed on the Indonesia Stock Exchange (2010-2014). Journal of Minds: Management of Ideas and Inspiration, 3 (1), 70-85.

Pratama, I. G. S., and Sudhiarta, G. M. (2014). Comparative Analysis of Stock Return Abnormal Before and After Announcement of Right Issue. E-Journal of Udayana University Management 3(1), 243-25

Putri, S. C. D., Maslichah, M., and Mawardi, M. C. (2018). Analysis of Investor Reactions to Announcements of Right Issues on the Indonesia Stock Exchange (Empirical Study of Companies Listed on the Indonesia Stock Exchange in 2012-2016). Scientific Journal of Accounting Research, 7 (01).

Ridho, A., Isynuwardhana, D., and Aminah, W. (2017). Analysis of Investor Reactions to Announcements of Right Issues on the Indonesia Stock Exchange for the 2013-2015 Period (an Observation on Abnormal Returns and Trading Volume Activities). eProceedings of Management, 4 (3)

Rohit, B., Pinto, P., and Bolar, S. (2016). Impact of stock splits and rights issue announcements on market price: Evidence from India. Drishtikon: A Management Journal, 7(2), 1-16. 
Salameh, H., and AlBahsh, R. (2011). Testing the Efficient Market Hypothesis at the Semi Strong Level in Palestine Stock Exchange-Event Study of the Mandatory Disclosure. International Research Journal of Finance and Economics, 69, 45-50.

Shahid, Humera, Xia Xinping, Faiq Mahmood, Muhamad Usman. (2010). Announcement Effects Of Seasoned Equity Offerings In China. International Journal of Economics And Finance, 2(3): pp:163-170.

Shihadeh, F., and Hannon, A. (2016). Is Palestine Exchange An Efficient Market In Semistrong Form, Interational Journal Of Economics, Commerce And Management, Vol 4, Issue 4, Pp 106-119

Wistawan, I. M. A. P., and Widanaputra, A. A. G. P. (2013). Impact of Stock Split Announcements on Abnormal Return Differences. E-Journal of Accounting, Udayana University, 5 (1).

Yalama, A., and Çelik, S. (2008). Financial market efficiency in Turkey: empirical evidence from Toda Yamamoto causality test. European Journal of Economics, Finance and Administrative Sciences. Year: 2008, Issue: 13 